\title{
New Possibilities for Reuse of Industrial Buildings and the Work of Re-FACT
}

\author{
Nové možnosti využitia industriálnych objektov \\ a práca komunity Re-FACT
}

\author{
Katarína Beláčková \\ Ústav památkové péče, Fakulta architektury, Vysoké učení technické v Brně \\ katus.belackova@gmail.com
}

\begin{abstract}
The Re-FACT community is a group of professors taking an interest in conversions of industrial buildings and in industrial archaeology. One of its members is professor Helena Zemánková from the Faculty of Architecture of the Brno University of Technology. An annual international workshop, focusing on projects concerning reuse of industrial structures, for students of architecture has been organized for the last ten years. Last year I had the chance to participate in the workshop named Silos Granari on a conversion of a silo that would turn it into a city symbol, and on an integration of the silo with the city: its possible functions in connection to the harbour and the city. In 2014, I took part in the workshop in Differdange where we were developing a concept for a turbine hall being converted into the Museum of New Technologies. Each workshop, taking place in a different part of Europe, is organized by a different member of the Re-FACT team. I would like to present the projects in which I participated and take a look at the impact the workshops have had on the localities and structures.
\end{abstract}

KEYWORDS: Re-FACT; silo granary; museum of technologies; Differdange; industrial architecture; workshop

ABSTRAKT: Re-FACT komunita je skupina profesorov zaoberajúcich sa otázkami konverzie priemyselných objektov, územným rozvojom a otázkami udržatelného rozvoja. Jedným z členov je aj profesorka Helena Zemánková pôsobiaca na Fakulte architektúry VUT v Brne. Každoročne sa už skoro desat' rokov organizuje medzinárodný workshop pre študentov architektúry, na ktorom sa riešia nové možnosti využitia priemyselných objektov. V minulom roku 2015 som mala možnoste zúčastnit 
sa workshopu s názvom Silos Granari. Riešila sa na ňom otázka prestavby sila ako symbolu mesta a jeho postavenie $\mathrm{k}$ nemu - spôsoby a možnosti jeho využitia v nadväznosti na prístav a mesto. V roku 2014 sa konal workshop v Differdange, kde sme riešili koncepciu turbínovej haly ako Múzeum nových technológií. Každý workshop je organizovaný iným členom Re-FACT tímu a teda aj v inej lokalite Európy. Chcela by som predstavit projekty, na ktorých som sa podielala a poohliadnut sa, aký dopad mal workshop na dané miesto či objekt.

KLÍČOVÁ SLOVA: Re-FACT; silo granary; múzeum technológií; Differdange; industriálna architektúra; workshop

\section{Úvod}

Otázka obnovy industriálnych objektov a priestorov, ktoré na ne nadväzujú, sa v súčasnosti stala vel’mi aktuálnou. Naše mestá v priebehu ich vývoja prešli transformáciou ako aktom obnovy. Počas industrializácie hlavne v priebehu 19. storočia došlo k zásadnej zmene, a to nielen ekonomickej, ale hlavne sociálnej. Tento silný impulz dal podnet $\mathrm{k}$ rýchlej urbanizácii miest, ich spriemyselňovaniu. Počas tejto éry sme prešli vel'kou zmenou technológie a poznania, rozvinuli mnoho oborov a rozšírili tak vedomosti celého ludstva, čo vybudovalo pevný základ pre vstup do 21. storočia k modernej spoločnosti, ktorej sme dnes súčastou. Nastáva však mnoho otázok, ako pristupovat’ k opusteným priemyselným objektom či areálom.

\section{Vznik Re-FACTu}

„Iniciatíva medzifakultných architektonických workshopov, ako inovativny didaktický prístup k priemyselnému dedičstvu, bol začatý v roku 2006 profesorom Klausom Dieter Köehlerom, ktorý pracuje (v súčasnosti ako dekan) na Fakulte architektúry HTW Saar of Saarbrücken $v$ Nemecku. Univerzity, ktoré ako prvé nadviazali na túto spoluprácu, boli Fakulta architektúry v Brne v Českej republike reprezentovaná profesorkou Helenou Zemánkovou, d’alej potom fakulta v Nancy vo Francúzku zastúpená profesorkou Jacques Fabbri, potom neskôr Christian François a v súčasnosti Jennifer Didelon. Flaviano Maria Lorusso, profesor Florenskej univerzity, sa pripojil do tímu, ako výsledok spolupráce medzi talianskou a nemeckou Fakultou architektúry založenou v roku 1999 architektkou Jennifer Schaub, ktorá je aktuálne koordinátorkou tohto workshopu. Vd’aka úsiliu profesora K. D. Köehlera v pokračujúcej propagácii a zmedzinárodňovaniu workshopu, spolupráca, ktorá začala so štyrmi partnermi, sa v súčasnosti počíta na šest' partnerov. Od roku 2012 sa pripojila University v Seville pod vedením profesora Benito Sánchez-Montañes a jeho kolegu Luis Gonzalez-Boado, a od roku 2014 sa do projektu 
zapájajú niektorí študenti z NYU.“ (Schaub, 2015)

„Re-FACT je meno vybrané partnerskými univerzitami v nadväznosti na ich dlhodobé skúsenosti s medzinárodnými workshopmi na tému obnovy industriálnych pamiatok $v$ hlbšom kontexte na urbanistickú regeneráciu, v záujme zdiel’ania a prehlbovania poznania ich výskumu.

Úlohou Re-FACTu je zosilnit medzinárodné partnerstvá a rozšírit’ vedeckú debatu a porovnávanie, štrukturovat', zjednocovat' - ucelovat' charakter vedeckých skúseností, ktoré vznikli v minulosti, a budúcich výskumných aktivít v konštantne vzrastajúci organizmus projektu. Vskutku aktivity Re-FACT vzrástli do rozmanitej učebnej a výskumnej činnosti, ako diplomové práce zahájené prácou na workshope alebo ako link $k$ jednotlivým výskumným aktivitám jednotlivých zapojených profesorov. Názov Re-FACT je výsledkom brainstormingu $v$ hlavných skúmaných objektoch, viac ako reflexiou postupu v nevyhnutných metodologických postupoch je reflexiou na historický a kultúrny, sociálno-ekonomický a environmentálne udržatelný, a to akýkolvek urbanistický či architektonický vývoj. Je to syntéza výrazov ako re-use, re-functionalize alebo re-activate, ale tiež re-design alebo re-admire." (Schaub, 2015)

\section{Program a koncepcia workshopov}

S pojmom Re-FACT som sa mala možnost’ prvýkrát oboznámit’ na Fakulte architektúry v Brne v roku 2014. Bolo to v ateliéri pani profesorky Zemánkovej, ktorá je aktívnou členkou Re-FACTu, a každoročne sa so skupinou študentov zúčastňuje workshopov. V roku 2010 usporiadala takýto workshop v Brne s názvom The prison house - Väznica. S dalšími štyrmi študentmi som sa ako študentka magisterského stupňa na záver letného semestra 2014 zúčastnila medzinárodného workshopu v Differdange. Ako študentka doktorského štúdia som sa na jeseň v roku 2015 zúčastnila workshopu organizovaného v Talianskom prístavnom meste Livorno.

Vel'kú výhodu medzinárodného workshopu vidím v možnosti zoznamovania sa s novými študentmi, ich profesormi, prístupom a pohladom na riešenie konceptu a spôsobu postupu práce a nástrojmi, ktoré sú zvyknutí používat na spracovanie návrhov. $\mathrm{Na}$ začiatku každého workshopu sme mali možnost’ navštívit’ riešený objekt a jeho okolie a vytvorit si tak ucelenú predstavu o jeho začlenení do urbanistickej štruktúry, hladaní jeho jedinečnosti v celku, ale aj v detailoch či zariadeniach. K pochopeniu širších vzṫahov sme mali možnost pristúpit pri vstupných prednáškach organizovaných hlavným organizátorom workshopu. Dostali sme pridelené digitálne podklady a každý musel vytvorit tím zložený zo študentov rôznych národností. V Differdange som tak spolupracovala s Piotrom Klímom, Eduardom Gonzalesom a Marion Comte. V Livorne to bol tím zložený z Jenifer Gebel, Karlosa Cardony, Darie Triponncini. 
Hlavným jazykom bola angličtina. Najdôležitejšia čast’ workshopu prebiehala v troch pracovných dňoch. Počas týchto troch dní sme mali malú kritiku, kde každá skupina predviedla svoj koncept a filozofiu svojho návrhu. Po tejto kritike sme mali deň a pol na dopracovanie prediskutovaných konceptov do zadaním predurčeného množstva plagátov a záverečnej prezentácie. Počas práce na projektoch sme našu prácu priebežne konzultovali s profesormi a odborníkmi na rôzne stránky projektu.

Takto spracovaný projekt každá skupina odprezentovala pred všetkými účastníkmi workshopu, profesormi a miestnymi autoritami. Velmi obohacujúca na tejto skúsenosti bola možnost’ zistit’, ako rýchlo sa dá rozvinút myšlienka či nápad, a možnost’ tímovej práce, ked’ sa musí v obmedzenom čase dôjst' ku konsenzu a rozdeleniu úloh na jednotlivých častiach projektu.

\section{Differdange-Lunbursko}

Zadaním workshopu v termíne 9.-16.5. 2014 bolo navrhnutie riešenia pre turbínovú halu, ktorá stála na okraji priemyselnej zóny mesta Differdange. Tento objekt mal byt novo zahrnutý do mestskej štruktúry svojou novou funkciou ako Múzeum technológií.

Koncept: Pred objektom sa nachádzala väčšia nevyužitá plocha zelene, s ktorou sa pracovalo v návrhu. $\mathrm{V}$ našom koncepte bolo dôležité nájst' nové spojenia, ktoré by prepojili mesto a halu pomyselne oddelenú cestnou i železničnou dopravou. Navrhli sme preto lávku, ktorá by $\mathrm{z}$ rezidenčnej štvrti priamo prechádzala $\mathrm{k}$ hlavnému vstupu do múzea. Pred turbínovou halou sa nachádzal ešte jeden menší, ale svojou polohou výraznejší objekt. Rozhodli sme sa ho preto zachovat a vytvorit v ňom vstupné priestory haly a reštaurácie. So zázemiami by sa tento objekt prepájal dalšou lávkou do turbínovej haly, ktorá by si ponechala svoju jedinečnú podobu. V interiéri boli navrhnuté malé kompaktné bunky, ktoré sprevádzali návštevníkov celou expozíciou a uzatvárali alebo naopak otvárali priestor smerom na expozíciu či vybavenie haly.

\section{Livorno-Taliansko}

V tomto historickom renesančnom meste sme v termíne 9.-17.10. 2015 riešili návrh novej funkcie objektu sila, ktorý stál v turistickom prístave na rozmedzí starého mesta a nákladnej a priemyselnej zóny. Tento nevyužitý objekt vizuálne dominuje lokalite, a to nielen z mesta, ale i z mora. Vytvára tak vstupnú bránu a dôležitý bod. Počas workshopu sme hladali možnosti jeho prestavby - prístavby, nového funkčného využitia. $Z$ oboch strán ho obkolesujú prístavné doky, kde počas sezóny kotvia vel'ké turistické lode. 
Z objektu sila sme vytvorili monument, v ktorom sa nachádzalo múzeum dokumentujúce históriu sila. Dramatické bolo hlavne obdobie 2. svetovej vojny, ked' bol celý prístav zničený bombardovaním, ale silo zostalo stát skoro neporušené. Prístavbu, ktorá k silu pribudla v 60. rokoch 20. storočia, sme očistili od fasády a funkčne vyplnili koncertnou sálou. Na celý tento objekt sme nadstavili moderný kubus, ktorý spájal tri celky do jedného kompaktného, ešte umocnenejšieho. V tejto časti preto vznikol hotel a reštaurácia s jedinečnými výhladmi.

\section{Záver}

Priemyselné objekty majú svoju industriálnu krásu. Sú to jedinečné objekty poskytujúce široké možnosti využitia. Je potreba vytvárat možnosti diskusie a hladania riešení. Projekty ako Re-FACT sú impulzmi v lokálnom prostredí. Vytvárajú priestor k diskusii odborníkov, rozvíjajú kreativitu študentov. Vo výsledku svojou akciou vytvárajú mnoho reakcií a záujmu obyvatelov týchto miest. Po skončení posledného workshopu v Livorne sa strhla vel'ká vlna záujmu. Mnoho študentov, ktorí sa ho zúčastnili, pokračovali s prácou na projekte sila aj po návrate prostredníctvom ateliérových projektov či diplomových prác. Hlavná koordinátorka, architektka Jennifer Schaub, zorganizovala v pevnosti Fortesa Vechia oproti silu výstavu všetkých dokončených projektov v meste Livorno.

Tak ako bol kedysi priemysel silným impulzom pre výstavbu, dnes prevláda hladanie nových možností využitia jeho starých objektov. V súčasnosti vzniká vela organizácií, ale je aj mnoho nadšencov, ktorí toto dedičstvo pomocou pestrej škály projektov a akcií premieňajú na komunitné centrá, ako napríklad Industra či Malá Amerika v Brne.

Na záver slovo osvieteného človeka, vd’aka ktorému sa v Industre (pôvodne chladiarenskom objekte) podarilo vyvolat záujem ludí a rozvinút pestrú škálu aktivít.

„V̌̌ichni občas zažíváme ,to jako fakt?' momenty, kdy nás překvapí, jak zbytečná, či prímo škodlivá rozhodnutí děláme. S trochou nadsázky lze říct, že je s podivem, že jsme ještě jako živočišný druh nevyhynuli. Na druhou stranu máme i neobyčejně světlé chvilky, kdy dokážeme překvapit, nadchnout a oslnit! Jsem přesvědčený, že přes všechna naše zaváhání jsme natolik dospělí, že dokážeme vědomě přecházet od náhodného k uvědomělému chování a že dokážeme dát našim životům smysl. Pro podporu této myšlenky jsem založil neziskovku Vaizard."(Stratil, 2015) 

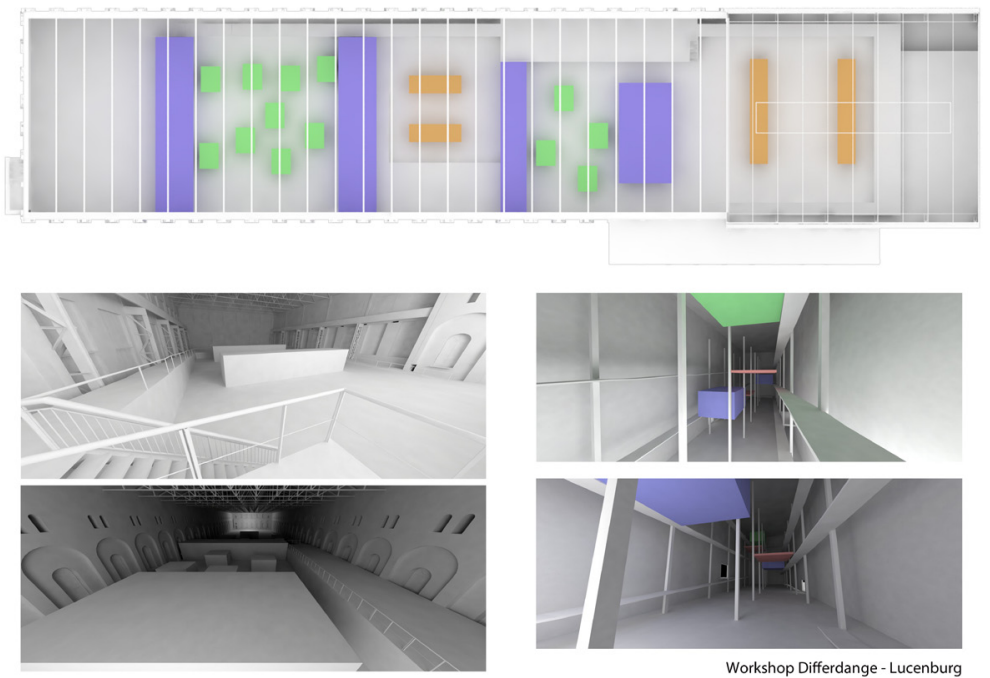

Obr. 1. Projekt koncept pre Múzeum technológii, Differdange (autori: Katarína Beláčková, Piotr Klíma, Eduardo Gonzales, Marion Comte)
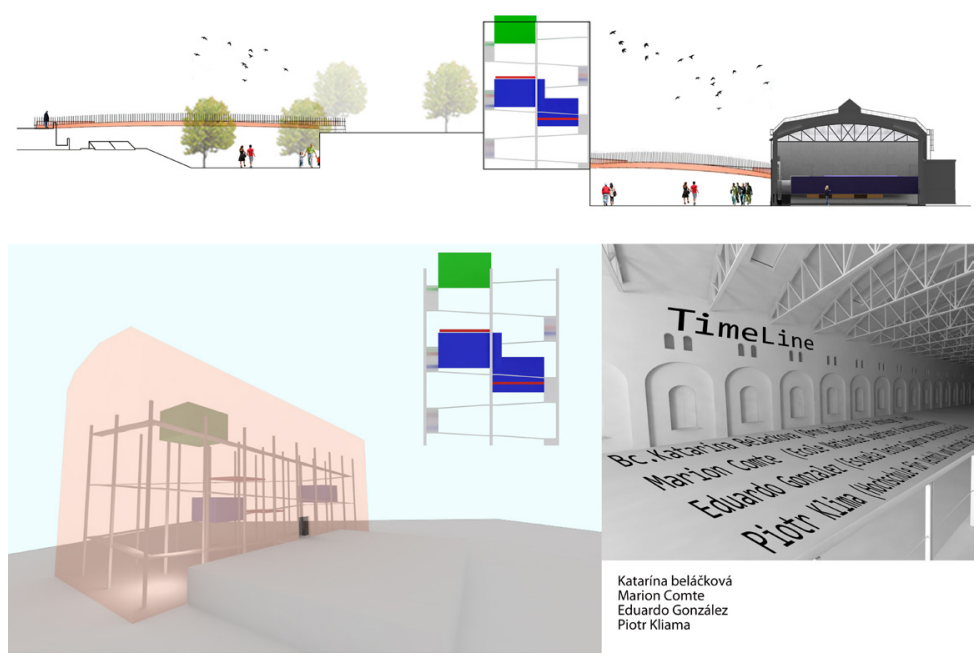

Obr. 2. Projekt koncept pre Múzeum technológii, Differdange (autori: Katarína Beláčková, Piotr Klíma, Eduardo Gonzales, Marion Comte) 

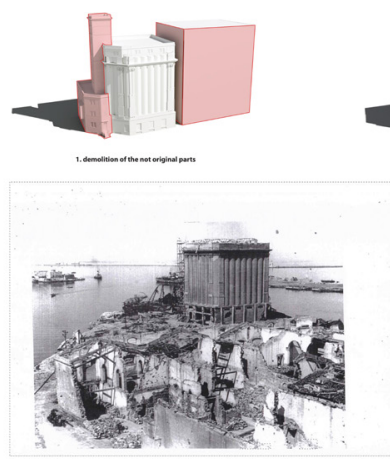
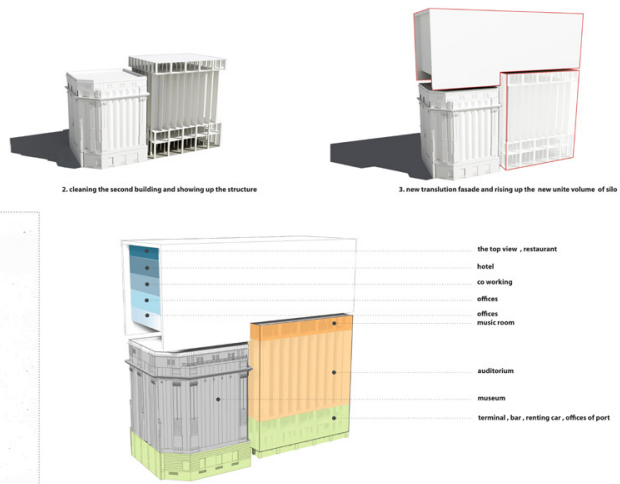

Obr. 3. Projekt koncept pre Silo, Livorno (autori: Katarína Beláčková, Jenifer Gebel, Karlos Cardona, Dario Triponncini)

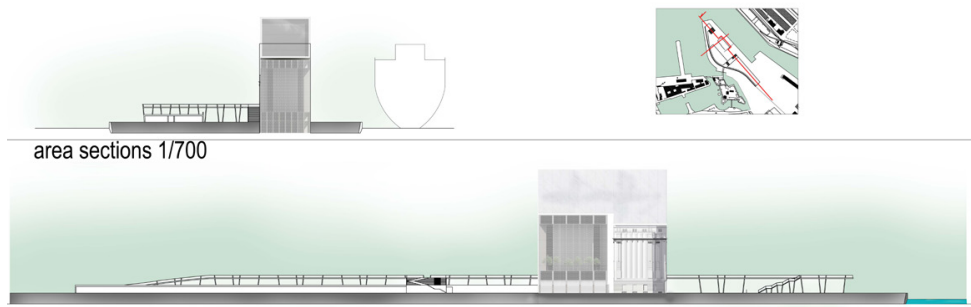

area sections in detail
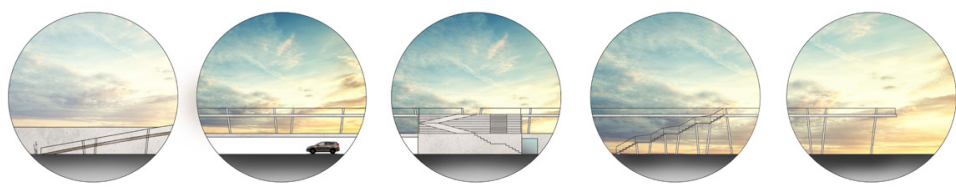

Obr. 4. Projekt koncept pre Silo, Livorno (autori: Katarína Beláčková, Jenifer Gebel, Karlos Cardona, Dario Triponncini) 


\section{Prameny}

SCHAUB, Jennifer. Why Re-FACT. c2015 , [cit. 2016-09-6]. < http://re-fact.org/ about $/>$.

SCHAUB, Jennifer. Why Re-FACT. c2015 , [cit. 2016-09-6]. < http://re-fact.org/evento/brno-2010/\#pres>.

SCHAUB, Jennifer. Why Re-FACT. c2015 , [cit. 2016-09-6]. < http://re-fact.org/evento/differdange-2014/\#pres>.

SCHAUB, Jennifer. Why Re-FACT. c2015 , [cit. 2016-09-6]. < http://re-fact.org/evento/silos-granari/\#home>.

SCHAUB, Jennifer. Why Re-FACT. c2014 , [cit. 2016-09-6]. <https://www.facebook. com/refact.workshop/?fref=ts $>$.

STRATIL, Pavel. Industra Př́iběh. c2014, [cit. 2016-09-6]. https://industrabrno.cz/cs/ pribeh/. 